\title{
Influence of Elements with High Affinity to Oxygen on Microstructure and Phase Composi- tion of Ni-Ti Alloy
}

Andrea Školáková, Pavel Novák, Pavel Salvetr

University of Chemistry and Technology in Prague, Department of Metals and Corrosion Engineering, Technická 5, 166 28 Prague 6, Czech Republic, E-mail: SkolakovaA@seznam.cz

\begin{abstract}
Approximately an equiatomic alloy of nickel and titanium is known as nitinol. Nitinol possesses a lot of interesting properties such as shape memory, pseudoplasticity, superelasticity and corrosion resistance. NiTi alloys are usually industrially produced by melting process, but the products have not good quality and purity. Powder metallurgy with reactive sintering is considered as one of the route of production of NiTi alloys. However, the other phases are formed during this process $\left(\mathrm{Ti}_{2} \mathrm{Ni}, \mathrm{Ni}_{3} \mathrm{Ti}\right)$. The presence of $\mathrm{Ti}_{2} \mathrm{Ni}$ phase is unwanted in this alloy. It is stabilized by oxygen and its main disadvantage is brittleness. In this work we prepared NiTi shape memory alloys by Self-propagating High-temperature Synthesis (SHS). Results showed the possibility of modification of the phase composition by alloying with other elements, which have higher affinity to oxygen. Carbon was found to reduce the amount of undesirable $\mathrm{Ti}_{2} \mathrm{Ni}$ phase, while in presence of zirconium this phase reduces its hardness which implies the loss of brittleness.
\end{abstract}

Keywords: NiTi alloy, Self-propagating High-temperature Synthesis, $\mathrm{Ti}_{2} \mathrm{Ni}$ phase

\section{Acknowledgement}

This research was financially supported by Czech Science Foundation, project No. 14-03044S.

\section{References}

[1] NOVÁK, P., MEJZLÍKOVÁ, L., MICHALCOVÁ A., ČAPEK J., BERAN P., VOJTĚCH D. (2013). Effect of SHS conditions on microstructure of NiTi shape memory alloy. In: Intermetallics, Vol. 42, pp. 85 - 91. Elsevier. Netherlands.

[2] WU, M. H. (2002). Fabrication of nitinol materilas and components. In: Materials Science Forum, Vol. 394, pp. 285 - 292. Trans Tech Publications. Switzerland.

[3] NYAN, N., GOVIND, SAIKRISHNA, C. N., VENKATA RAMAIAH, K., BHAUMIK, S. K., SUSEELAN NAIR, K., MITTAL, M. C. (2007). Vacuum induction melting of NiTi shape memory alloys in graphite crucible. In: Materials Science and Engineering: A, Vol. 465, No. 1-2, pp. 44 - 48. Elsevier. Netherlands.

[4] YI, H. C., MOORE, J. J. (1988). A novel technique for producing NiTi shape memory alloy using the thermal explosion mode of combustion synthesis. In: Scripta Metallurgica, Vol. 22, No. 12, pp. 1889 - 1892. Elsevier. Netherlands.

[5] ITIN, V. I., GYUNTER, V. E., SHABALOVSKAYA, S. A., SACHDEVA, R. L. C. (1994). Mechanical properties and shape memory of porous nitinol. In: Materials Characterization, Vol. 32, No. 3, pp. 179 - 187. Elsevier. Netherlands.

[6] WHITNEY, M., CORBIN, S. F., GORBET, R. B. (2008). Investigation of the mechanism of reactive sintering and combustion synthesis of NiTi using differential scanning calorimetry and microstructural analysis. In: Acta Materialia, Vol. 56, No. 3,pp. 559 - 570. Elsevier. Netherlands.

[7] NOVÁK, P., VESELÝ, T., MAREK, I., DVOŘÁK, P., VOJTĚCH, V., SALVETR, P., KARLÍK, M., HAUŠILD, P., KOPEČEK, J. (2016). Effect of particle size of titanium and nickel on the synthesis of NiTi by TE-SHS. In: Metallurgical and Materials Transactions B, Vol. 47, No. 2, pp. 932 - 938. Springer. Germany.

[8] NOVÁK, P., SALVETR, P., PECENOVÁ, Z. (2015). Intermetallics - Synthesis, Production, Properties. In: Manufacturing Technology, Vol. 15, No. 6, pp. 1024 - 1028. UJEP. Czech Republic.

[9] NOVÁK, P., POKORNÝ, P., VOJTĚCH, V., KNAISLOVÁ, A., ŠKOLÁKOVÁ, A., ČAPEK, J., KARLÍK, M., KOPEČEK, J. (2015). Formation of $\mathrm{Ni}-\mathrm{Ti}$ intermetallics during reactive sintering at $500-650{ }^{\circ} \mathrm{C}$. In: Materials Chemistry and Physics, Vol. 155, pp. 113 - 121. Elsevier. Netherlands. 
[10] NOVÁK, P., MICHALCOVÁ, A., ŠKOLÁKOVÁ, A., PRŮŠA, F., KŘÍŽ, J., MAREK, I., KUBATÍK, T. F., KARLÍK, M., HAUŠILD, P., KOPEČEK, J. (2015). Effect of heating rate on the formation of intermetallics during SHS process. In: Acta Physica Polonica A, Vol. 128, No. 4, pp. 561 - 564. Instytut Fizyki. Poland.

[11] NOVÁK, P., ŠKOLÁKOVÁ, A., VOJTĚCH, V., KNAISlOVÁ, A., POKORNÝ, P., MORAVEC, H., KOPEČEK, J., KARLÍK, M., KUBATÍK, T. F. (2014). Applications of microscopy and x-ray diffraction in optimization of the production of NiTi alloy by powder metallurgy. In: Manufacturing Technology. Vol. 14, No. 3, pp. 387 - 392. UJP. Czech Republic.

[12] NEVITT, M. V. (1960). Stabilization of certain amount $\mathrm{Ti}_{2} \mathrm{Ni}$-type phases by oxygen. In: Transactions of the Metallurgical Society of AIME, Vol. 218, pp. 327 - 331. American Institute of Mining, Metallurgical and Petroleum Engineers. USA.

[13] SALVETR, P., NOVÁK, P., MORAVEC, H. (2015). Ni-Ti alloys produced by powder metallurgy. In: Manufacturing technology, Vol. 15, No. 4, pp. 689 - 694. UJP. Czech Republic.

[14] KUČERA, V., ČAPEK, J., MICHALCOVÁ, A., VOJTĚCH, D. (2014). Preparation and characterization of NiTi shape memory alloy prepared by powder metallurgy. In: Manufacturing Technology, Vol. 14, No. 3, pp. 342 351. UJP. Czech Republic.

[15] NOVÁK, P., KRISTIÁNOVÁ, E., VALALÍK, M., DARME, C., SALVETR, P. (2015). New composite materials based on NiTi. In: Manufacturing Technology, Vol. 14, No. 3, pp. 644 - 647. UJP. Czech Republic.

[16] DU, J., WEN, B., MELNIK, R., KAWAZOE, Y. (2014). First-principles studies on structural, mechanical, thermodynamic and electronic properties of Ni-Zr intermetallic compounds. In: Intermetallics, Vol. 54, pp. 110 - 119. Elsevier. Netherlands.

[17] MASSALSKI, T. B. (1990). Binary Alloy Phase Diagrams, ASM, Materials Park. 